\title{
Pertumbuhan dan Kandungan Bahan Bioaktif Selaginella plana dan Selaginellla willdenovii pada Beberapa Media Tanam
}

\author{
MIFTAHUDIN*, DWI SUCI SETYANINGSIH, TATIK CHIKMAWATI \\ Departemen Biologi, Fakultas Matematika dan Ilmu Pengetahuan Alam, Institut Pertanian Bogor, Bogor 16680, Indonesia
}

Diterima 7 November 2014/Disetujui 21 Desember 2014

\begin{abstract}
Selaginella, a genus of Pteridophyte, is known as an herb that contains of several bioactive compounds. The growth and bioactive compounds of plant were affected by plant environment, such as media types. The objective of the research was to obtain an appropriate plant media for growing $S$. plana dan $S$. willdenovii, and its effect on the content of bioactive compounds. The experiment consisted of two factors, plant growth media and the species of Selaginella. The first factor consisted of eight plant growth media, i.e.: soil, rice husk, rice husk : soil $=1: 1(\mathrm{v} / \mathrm{v})$, burned rice husk, soil : burned rice huks $=1: 1(\mathrm{v} / \mathrm{v})$, burned rice husk : rice husk $=1: 1(\mathrm{v} / \mathrm{v})$, burned rice husk : rice husk $=3: 1(\mathrm{v} / \mathrm{v})$, and burned rice husk : rice husk $=1: 3(\mathrm{v} / \mathrm{v})$. The second factor was two spesies of Selaginella, i.e.: S. plana and $S$. willdenovii. Ethanol extract of Selaginella was qualitatively analyzed for flavonoid, tannin, and saponin content. The result showed that both fresh and dry weights of Selaginella were influenced by the type of plant media, Selaginella species, and their interactions. S. plana and $S$. willdenovii grew best on medium containing soil: burned rice $=1: 1(\mathrm{v} / \mathrm{v})$. The highest flavonoid content of $S$. plana and $S$. willdenovii was also obtained from the plant grown on the same media. Comparing to the bioactive compound content of natural plant, saponin content of $S$. plana and $S$. willdenovii was increased by the treatment of plant media. The treatment also increased tannin content of $S$. plana, but not of $S$. Willdenovii.
\end{abstract}

Key words: Selaginella, plant media, bioactive compounds

\section{PENDAHULUAN}

Lingkungan yang tercemar, radiasi ultra violet yang tinggi, bahan-bahan polutan, dan radikal lain yang menyebabkan cekaman oksidatif adalah masalah sehari-hari yang dihadapi manusia pada masa kini. Pemanfaatan tumbuhan obat sebagai sumber anti oksidan menjadi pilihan penting untuk mencegah timbulnya berbagai macam penyakit. Tumbuhan yang tumbuh di bumi nusantara ini banyak yang bermanfaat sebagai obat. Jumlah yang terlacak setidaknya mencapai 940 jenis tumbuhan berkhasiat obat (Erlan 2005). Salah satunya adalah Selaginella atau dikenal oleh masyarakat Sunda sebagai paku rane.

Selaginella memiliki perawakan herba dengan batang sebagian berbaring dan sebagian tegak, cabang menggarpu, dan anisotom. Pada batang terdapat daun-daun kecil seperti sisik $( \pm 5 \mathrm{~mm})$ yang tersusun dalam garis spiral atau berhadapan dalam empat baris. Dua baris diantaranya terdiri atas daun-daun yang lebih besar dan tersusun ke samping, sedangkan dua baris yang lain terdiri atas daun-daun yang lebih kecil terdapat pada sisi atas cabang-cabang dan menghadap ke muka. Daun

*Penulis korespondensi. Phone: $+62-81339711945$ E-mail:miftahudinm@gmail.com fertil tersusun pada setiap ujung cabang membentuk strobilus (Tjitrosoepomo 1994).

Selaginella memiliki banyak manfaat diantaranya sebagai bahan makanan, obat-obatan, tanaman hias, dan juga kerajinan. Manfaat Selaginella sebagai obat berasal dari kandungan bahan bioaktif yang dimilikinya. Penelitian sebelumnya melaporkan Selaginella yang berasal dari pulau Jawa mengandung beberapa bahan bioaktif, seperti flavonoid, alkaloid, steroid, tanin, dan saponin (Chikmawati et al 2012) yang bermanfaat untuk pengobatan penyakit tertentu. Flavonoid yang terkandung pada S. plana bermanfaat sebagai antioksidan (Gayathri et al 2005). Robusflavon dalam S. willdenovii adalah suatu biflavonoid penghambat perkembangan virus hepatitis B secara in vitro, penghambat kuat virus influensa A dan B dan penghambat sedang HSV-1 dan 2 (Lee et al. 1999; Lin et al. 2000). Di negara Jepang dan Cina, tanin digunakan sebagai senyawa anti inflamatori dan antiseptik, dan juga dimanfaatkan sebagai bahan obat penyakit diare dan tumor usus dua belas jari (Nicholson 2006). Selain itu, beberapa saponin khusus memiliki efek antitumor, contohnya ginsenoides yang dihasilkan oleh tumbuhan damar. Ginsenoides bermanfaat dalam menghambat tumor dengan cara menekan pemicu dalam sel-sel endothelial dari pembuluh darah, dan metastasis dari sel-sel tumor (Man et al 2010). 
Sebagian besar tumbuhan obat dikoleksi langsung dari alam, sehingga apabila eksploitasi ini dilakukan berlebihan akan mengancam kelestarian tumbuhan tersebut (Joy et al 1998). Untuk menjaga kelestarian tumbuhan di alam maka usaha budidaya harus dikembangkan.

Studi sebelumnya terhadap produksi biomasa dan bahan aktif kolesom pada berbagai komposisi media tanam menunjukkan bahwa kandungan bahan aktif sangat dipengaruhi oleh lingkungan tumbuh tumbuhan, seperti media tanam (Susanti 2006). Untuk menunjang pertumbuhannya, Selaginella membutuhkan kondisi lingkungan yang memenuhi syarat tumbuhnya. Salah satu kondisi lingkungan yang harus terpenuhi adalah jenis media tumbuh yang sesuai. Menurut Marlina dan Rusnandi (2007), media tumbuh merupakan salah satu faktor lingkungan yang berfungsi sebagai tempat tumbuhnya akar tanaman, penopang tanaman agar tumbuh dengan baik, dan menyediakan unsur hara dan air bagi pertumbuhan tanaman. Beberapa macam media yang dapat digunakan sebagai media tumbuh tanaman yaitu tanah, sekam, dan arang sekam. Sekam padi mengandung unsur nitrogen dan kalium. Selain itu memiliki karakter ringan, memiliki drainase dan aerasi yang baik, tidak mempengaruhi $\mathrm{pH}$, mengandung hara atau larutan garam, mempunyai kapasitas menyerap air, dan harganya murah (Marlina \& Rusnandi 2007). Sekam bakar berasal dari sekam padi yang disangrai sampai hitam tetapi bentuknya masih utuh dan tidak sampai menjadi abu. Sekam bakar bersifat steril (Risa 2007).

Artikel ini melaporkan hasil penelitian tentang pengaruh delapan jenis media tanam terhadap pertumbuhan dan kandungan bahan aktif S. plana dan S. willdenovii.

\section{BAHAN DAN METODE}

Bahan Percobaan. Bahan tanaman yang digunakan adalah dua spesies Selaginella, S. plana dan S. willdenovii yang berasal dari lokasi sekitar Fakultas Perikanan Kampus IPB Darmaga. Bahan lain yang digunakan dalam penelitian ini meliputi tanah, sekam, arang sekam, kompos, akuades, etanol $70 \%$, serbuk $\mathrm{Mg}, \mathrm{HCl}$ pekat, amil alkohol, dan $\mathrm{FeCl}$ $10 \%$.

Rancangan Percobaan. Penelitian ini merupakan percobaan faktorial dengan rancangan acak lengkap. Percobaan terdiri atas dua faktor yaitu jenis media tanam dan jenis Selaginella. Faktor media terdiri atas delapan taraf, yaitu media tanam dari tanah, sekam padi, dan arang sekam, yang dikombinasikan dalam perlakuan dengan perbandingan volume : volume sebagai berikut: $\mathrm{M} 0=$ tanah, $\mathrm{M} 1=$ sekam, $\mathrm{M} 2=$ tanah : sekam $=1: 1, \mathrm{M} 3=$ arang sekam M4 = tanah $:$ arang sekam $=1: 1$, M5 $=$ sekam $:$ arang sekam $=1: 1$, M6 $=$ sekam $:$ arang sekam $=3: 1, \mathrm{M} 7=$ sekam $:$ arang sekam $=1: 3$. Masing-masing media ditambahkan pupuk kompos sebanyak seperdelapan dari volume media untuk memenuhi nutrisi tumbuhan. Faktor jenis Selaginella terdiri atas dua taraf yaitu S. plana dan S. willdenovii. Setiap perlakuan diulang tiga kali.

Penanaman Bibit. Bibit tanaman merupakan seluruh bagian tanaman Selaginella. Bibit ditanam ke dalam polibag berukuran $15 \mathrm{~cm}$ x $15 \mathrm{~cm}$ yang telah terisi media tanam perlakuan untuk aklimatisasi selama satu minggu. Satu bulan setelah tanam, tanaman dipindah ke dalam polibag berukuran $20 \mathrm{~cm}$ x $25 \mathrm{~cm}$ yang berisi media tanam sesuai perlakuan. Seluruh tanaman diberi naungan menggunakan paranet dengan kerapatan $80 \%$.

Pemeliharaan Tanaman. Pemeliharaan terdiri atas penyiraman, penyiangan, dan pengendalian penyakit tanaman. Penyiraman dilakukan dua hari sekali. Penyiangan dengan mencabut gulma yang tumbuh di sekitar tanaman. Pengendalian penyakit tanaman dengan penyemprotan fungisida pada media yang ditumbuhi cendawan.

Pengamatan. Pengamatan terdiri dari penghitungan jumlah cabang yang dilakukan satu minggu sekali. Pengukuran bobot basah dan bobot kering dilakukan setelah pemanenan (tiga bulan setelah tanam). Pengukuran bobot basah dan bobot kering dilakukan dengan prosedur sebagai berikut : tanaman dipanen dan dicuci dengan air bersih, lalu dikeringanginkan. Kemudian dilakukan penimbangan bobot basah. Setelah itu tanaman dibungkus dengan menggunakan kertas koran, kemudian dikeringkan menggunakan oven dengan suhu $50^{\circ} \mathrm{C}$ selama tiga hari. Setelah itu dilakukan penimbangan bobot kering tanaman.

Penyiapan Ekstrak Selaginella. Sampel tanaman yang digunakan, selain berasal dari tanaman yang telah diberi perlakuan juga yang berasal dari alam (lokasi di sekitar Fakultas Perikanan Kampus IPB Darmaga). Seluruh bagian tanaman yang telah dikeringkan, dihaluskan hingga menjadi tepung. Ekstrak etanol dari Selaginella dilakukan berdasarkan metode Gayathri et al (2005). Tepung kering Selaginella diekstrak menggunakan etanol $70 \%$ dengan pengadukan tetap selama 4 jam dan kemudian disaring dengan kertas saring. Filtrat kemudian dipekatkan pada rotary evaporator pada suhu $60^{\circ} \mathrm{C}$ selama 6 jam. Hasil pemekatan kemudian dikeringkan dengan menggunakan freeze dryer.

Analisis kualitatif kandungan bahan bioaktif. Analisis kandungan bahan bioaktif secara kualitatif 
meliputi uji kandungan flavonoid, tanin, dan saponin pada Selaginella. Sebanyak 0.1g ekstrak dimasukkan ke dalam tabung reaksi kemudian ditambahkan $5 \mathrm{ml}$ akuades. Setelah itu dipanaskan selama 5 menit pada penangas air dan disaring. Hasil saringan (filtrat) dibagi tiga dan masing-masing diberi perlakuan berbeda untuk uji keberadaan flavonoid, tanin, dan saponin mengikuti prosedur yang dikembangkan oleh Gayathri et al (2005). Uji flavonoid dilakukan dengan cara filtrat ditambah dengan 5 tetes $\mathrm{HCl}$ pekat, 5 tetes amil alkohol, dan serbuk Mg. Hasil dinyatakan positif apabila terbentuk warna jingga. Uji kandungan saponin dilakukan dengan cara filtrat dikocok kuatkuat beberapa kali. Hasil dinyatakan positif apabila buih yang terbentuk stabil. Uji kandungan tanin dilakukan dengan cara filtrat ditambah 3 tetes $\mathrm{FeCl}$ $10 \%$. Hasil dinyatakan positif apabila terbentuk warna hitam kehijauan.

Analisis media tanam. Analisis ini meliputi pengukuran $\mathrm{pH}, \mathrm{C}, \mathrm{N}$ total, $\mathrm{P}, \mathrm{K}, \mathrm{Ca}, \mathrm{Mg}$. Analisis media tanam sebelum percobaan dilakukan di Laboratorium Kesuburan Tanah, Departemen Ilmu Tanah dan Sumberdaya Lahan Fakultas Pertanian IPB.

Analisis data. Data hasil percobaan di analisis menggunakan sidik ragam dan dilakukan uji lanjutan dengan Uji Berganda Duncan pada taraf kepercayaan $5 \%$.

\section{HASIL}

Kondisi Umum Tanaman. Selaginella plana memiliki batang sebagian berbaring dan sebagian tumbuh tegak. Daun berwarna hijau muda hingga hijau tua. Akar keluar dari ujung batang utama. S.plana tumbuh merumpun dengan daun-daun baru muncul baik pada batang utama maupun pada cabang baru,disertai pertumbuhan daun yang semakin membesar. Selaginella willdenovii memiliki batang utama berwarna merah kecoklatan tumbuh tegak, sedangkan cabangnya berbaring. Daun berwarna hijau kebiruan. Akar-akar keluar dari ujung batang utama. Pertumbuhan tanaman ini ada yang membentuk daun-daun baru, namun pertumbuhan lebih banyak ditunjukkan pada semakin membesarnya daun-daun pada batang utama.

Pertambahan Jumlah Cabang. Pertambahan jumlah cabang tidak dipengaruhi oleh jenis media, jenis Selaginella, dan interaksi antar keduanya. Meskipun demikian, pada 14 minggu setelah tanam kombinasi media tanah dan arang sekam (1:1) cenderung mendorong pertambahan cabang yang terbaik, dan S. plana cenderung memiliki jumlah cabang lebih banyak dari S. willdenovii (Gambar 1).
Bobot Basah. Hasil percobaan menunjukkan bahwa jenis media, jenis Selaginella dan interaksinya berpengaruh terhadap bobot basah biomasa tanaman (Gambar 2a). Secara umum S.plana memiliki

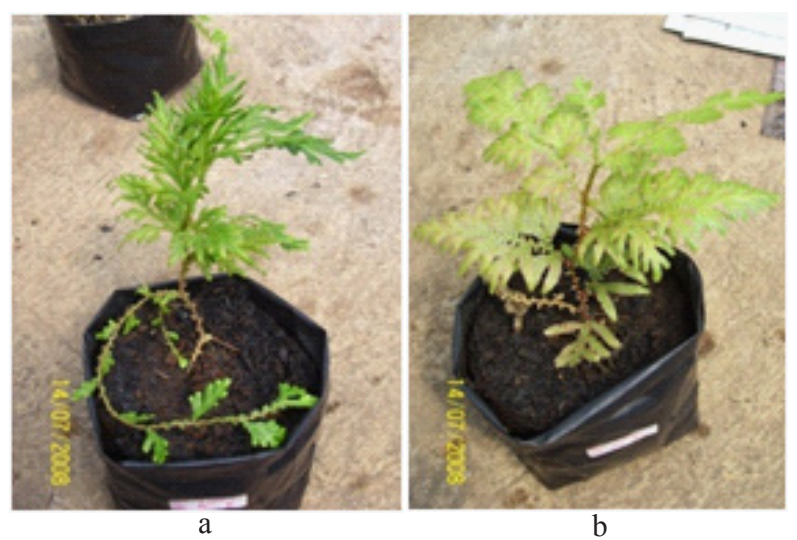

Gambar 1. Percabangan pada perlakuan kombinasi media tanah dan arang sekam (1:1). a. S. plana, b. S.willdenovii.
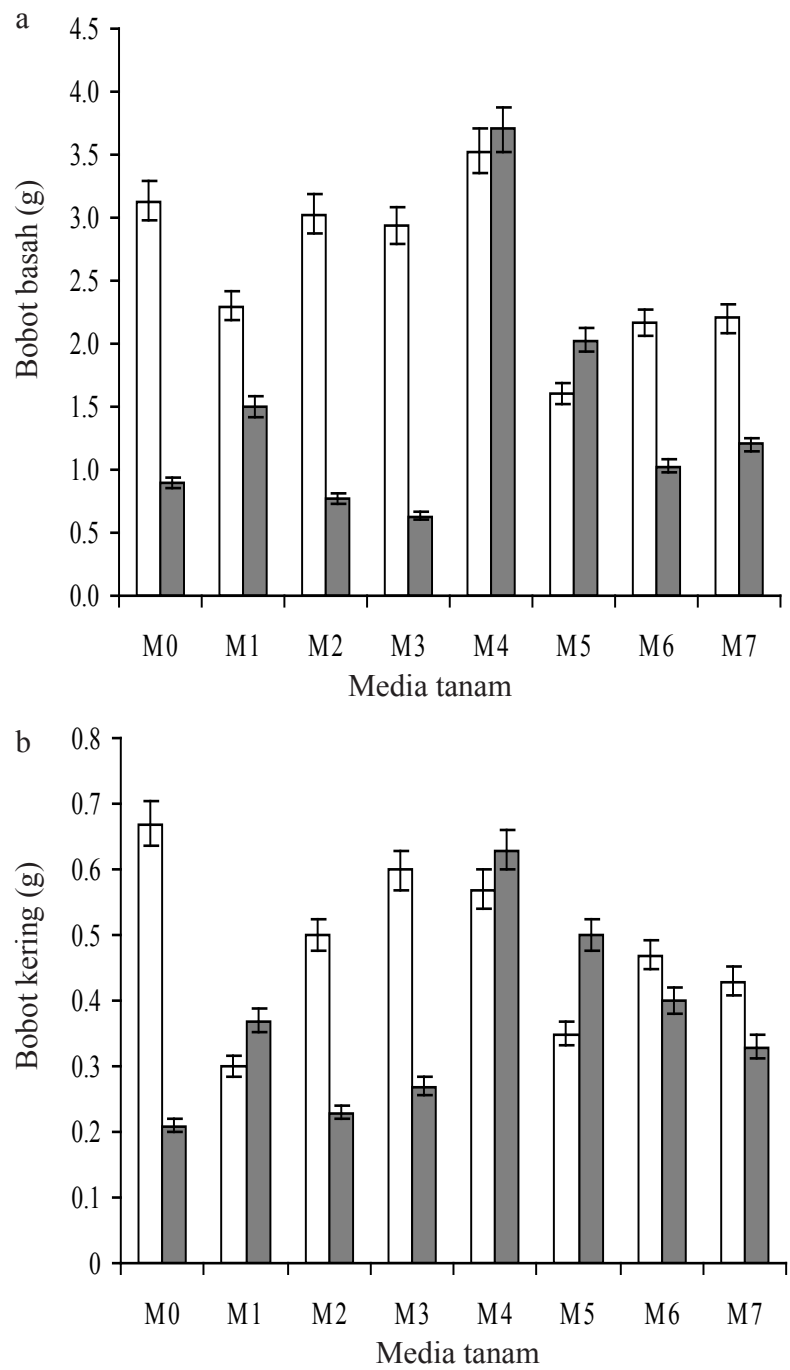

Gambar 2. Diagram batang bobot basah (a) dan bobot kering (b) dua jenis Selaginella pada berbagai media tanam. $\mathrm{MO}=100 \%$ tanah, $\mathrm{M} 1=100 \%$ sekam, M2=tanah: sekam =1:1, M3=arang sekam 100\%, M4=tanah: arang sekam $=1: 1$, M5=sekam: arang sekam $=1: 1$, M6=sekam : arang sekam = 3:1, M7=sekam : arang sekam $=1: 3 . \square S$. plana, $\square$ S. willdenovii. 
bobot basah lebih tinggi atau relatif sama dengan S. willdenovii pada semua media. Kedua jenis Selaginella menghasilkan bobot basah tertinggi pada media tanah : arang sekam (1:1) (Gambar 2a).

Bobot Kering. Bobot kering tanaman dipengaruhi oleh jenis media, jenis Selaginella dan interaksinya (Gambar 2b). Secara umum S. plana memiliki bobot kering lebih tinggi atau relatif sama dengan S. willdenovii pada semua media, kecuali pada media sekam : arang sekam (1:1). S. plana dapat menghasilkan bobot kering biomasa tertinggi apabila ditanam pada media tanah, arang sekam atau kombinasi media tanah : arang sekam (1:1), sedangkan $S$. willdenovii memperlihatan hal yang sama apabila ditanam pada media tanah : arang sekam (1:1) (Gambar2b).

Analisis Kualitatif Kandungan Bahan Bioaktif. Analisis kandungan bahan bioaktif dari ekstrak etanol Selaginella yang dilakukan secara kualitatif menunjukkan bahwa kedua jenis Selaginella mengandung flavonoid, tanin, dan saponin pada kadar yang berbeda beda bergantung media tanam yang digunakan. Kandungan flavonoid S. plana dan $S$. willdenovii tertinggi terdapat pada perlakuan kombinasi media tanah dan sekam (1:1) (Tabel 1). Pada S. plana kandungan saponin tertinggi terdapat pada media arang sekam dan kombinasi media sekam : arang sekam (1:1). Pada $S$. willdenovii kandungan saponin tertinggi terdapat pada perlakuan kombinasi media sekam : arang sekam (3:1) (Tabel 1). Pada $S$. plana kandungan tanin tertinggi terdapat pada perlakuan media tanah dan kombinasi media tanah : arang sekam (1:1) (Tabel 1).

Kandungan flavonoid dari kedua jenis Selaginella yang diambil dari alam cukup tinggi, tetapi kandungan saponin sangat rendah atau bahkan tidak terdeteksi pada S.willdenovii (Tabel 1). Kandungan tanin S.willdenovii pada semua perlakuan media tanam tidak meningkat. Kandungan tanin S. willdenovii yang diambil dari alam jauh lebih tinggi dibandingkan dengan kandungan tanin pada $S$. plana dari alam.

\section{PEMBAHASAN}

Tanaman percobaan ditanam pada media tanam dengan komposisi yang telah ditentukan dan ditempatkan di rumah kaca, dengan naungan $80 \%$. Penentuan keseragaman tanaman dilihat dari besar tanaman secara visual. Pada awal percobaan kondisi tanaman mengalami sedikit tercekam. Namun tanaman kembali terlihat tumbuh segar setelah melewati masa aklimatisasi selama satu minggu pada media tanam yang baru.

Hasil pengamatan menunjukkan bahwa kombinasi media tanah : arang sekam (1:1) cenderung memberikan respon jumlah cabang yang terbaik. Kondisi ini memungkinkan tanaman dapat berfotosintesis dengan baik dan menyerap nutrisi dengan lancar. Dari hasil pengamatan menunjukkan perlakuan kombinasi media sekam dan arang sekam (1:3) cenderung menghasilkan jumlah cabang terendah. Hal ini diduga karena sifat porous yang tinggi pada kombinasi arang sekam dan sekam, dan kandungan hara yang rendah sehingga kurang mampu untuk menahan air. Akibatnya tanaman yang ditumbuhkan pada kombinasi media tersebut mudah mengalami kekeringan dan menunjukkan pertumbuhan yang kurang baik.

Hasil pengamatan terhadap bobot basah tanaman menunjukkan bahwa perlakuan kombinasi tanah dan arang sekam (1:1) memberikan bobot basah tertinggi, baik pada $S$. plana maupun $S$. willdenovii. Hal ini mengindikasikan bahwa kombinasi media tanah dan arang sekam (1:1) merupakan kombinasi yang cocok untuk pertumbuhan kedua jenis tanaman tersebut. Diduga kombinasi media ini memberikan kemampuan menyediakan air dan nutrisi yang tinggi, sehingga mempengaruhi bobot basah tanaman. Sebaliknya

Tabel 1. Kandungan bahan bioaktif tanaman S. plana dan S. willdenovii

\begin{tabular}{|c|c|c|c|c|c|c|}
\hline \multirow{2}{*}{ Media } & \multicolumn{2}{|c|}{ Flavonoid } & \multicolumn{2}{|c|}{ Saponin } & \multicolumn{2}{|c|}{ Tanin } \\
\hline & S. plana & S. willdenovii & S. plana & S. willdenovii & S. plana & S. willdenovii \\
\hline M0 & +++ & ++ & ++ & ++ & ++++ & ++ \\
\hline M1 & + & + & +++ & + & + & + \\
\hline M2 & ++++ & ++++ & ++ & +++ & +++ & +++ \\
\hline M3 & ++ & +++ & +++ & ++++ & +++ & +++ \\
\hline M4 & + & +++ & +++ & +++ & ++++ & + \\
\hline M5 & +++ & ++ & ++++ & +++ & ++ & ++ \\
\hline M6 & ++ & +++ & + & ++++ & +++ & ++ \\
\hline M7 & + & ++ & +++ & ++ & + & +++ \\
\hline Alam & ++++ & +++ & + & - & + & ++++ \\
\hline
\end{tabular}

-: Tidak ada, +: Ada sedikit, ++: Cukup banyak, +++: Banyak, ++++: sangat banyak, M0: tanah, M1: sekam, M2: tanah:sekam $=1: 1, \mathrm{M} 3=$ arang sekam, M4 = tanah $: \operatorname{arangsekam}=1: 1, \mathrm{M} 5=$ sekam $: \operatorname{arangsekam}=1: 1$, M6 $=$ sekam $:$ arang sekam $=3: 1$, $\mathrm{M} 7=$ sekam : arang sekam $=1: 3$. 
perlakuan kombinasi media sekam dan arang sekam (3:1) menghasilkan bobot basah tanaman terendah. Hal ini diduga karena kombinasi kedua media tersebut tidak mampu menahan air dan menyediakan hara dalam jumlah yang cukup. Dengan demikian baik sekam maupun arang sekam harus dikombinasikan dengan media yang memiliki kemampuan menyimpan air yang tinggi dan memiliki kandungan hara yang cukup (Risa 2007).

Secara umum S. plana memiliki bobot kering ratarata lebih tinggi dari S. willdenovii. Hasil penelitian ini menunjukkan bahwa setiap jenis tanaman akan menunjukkan pertumbuhan yang berbeda ketika dikembangbiakkan secara vegetatif. Hasil ini sesuai dengan penelitian sebelumnya yang dilakukan oleh Sitompul dan Guritno (1995).

Pada kedua jenis Selaginella yang diteliti, kombinasi media tanah dan arang sekam (1:1) memberikan bobot kering tanaman tertinggi, tetapi media sekam memberikan respon bobot kering terendah. Dari hasil perbandingan menunjukkan bahwa kombinasi media tanah dan arang sekam (1:1) memberikan respon pertumbuhan terbaik berdasarkan seluruh peubah yang diamati. Hal ini diduga karena komposisi media ini memberikan kecukupan hara dan ketersediaan air yang dibutuhkan bagi pertumbuhan kedua jenis Selaginella karena kesuburan tanah dan tersedianya air sangat penting untuk mempertahankan aktivitas metabolisme, status kandungan mineral, dan kandungan airnya (Suseno 1972). Penambahan abu sekam pada tanah akan memperbaiki sifat fisik dan kimia tanah dengan menjadikan tanah lebih gembur sehingga perakaran dapat berkembang baik dan tanaman menjadi lebih kokoh (Dhalimi 2003). Kombinasi media tanah dan arang sekam (1:1) memiliki kandungan $\mathrm{N}, \mathrm{P}$, $\mathrm{K}$ berturut-turut $0.28 \%, 0.22 \%, 0.15 \%$ (Tabel 2). Namun data ini tidak menunjukkan kandungan unsur hara yang tersedia dari masing-masing media bagi pertumbuhan tanaman. Nitrogen $(\mathrm{N})$ merupakan komponen pembentuk banyak jenis molekul, diantaranya protein, asam amino, dan komponen penyusun klorofil. Fosfor $(\mathrm{P})$ berperan penting dalam proses fotosintesis, pembentukkan nukleotida, ADP, ATP, maupun gula terfosforilasi, sedangkan kalium (K) merupakan unsur yang penting dalam proses enzimatik, yaitu sebagai aktivator enzim termasuk enzim-enzim dalam respirasi dan fotosintesis (Taiz \& Zeiger 2006). Untuk pertumbuhan yang optimal diperlukan ketersediaan hara yang cukup. Secara umum $\mathrm{pH}$ media tanam mendekati netral atau pada tingkat ideal (Tabel 2) sehingga tanaman masih dapat tumbuh dengan baik pada kondisi tersebut. Kandungan unsur hara makro C, N, P, K, Ca, Mg, serta $\mathrm{pH}$ terlihat bervariasi dari seluruh media (Tabel 2). Pada media yang tidak mengandung tanah terlihat kandungan $\mathrm{C}$ dan $\mathrm{N}$ lebih tinggi dari kandungan $\mathrm{C}$ dan $\mathrm{N}$ dari media yang mengandung tanah. Hal ini dimungkinkan karena unsur tersebut banyak terdapat pada sekam, tetapi mungkin tidak tersedia bagi tanaman, sehingga pertumbuhan tanaman pada media tersebut kurang baik jika dibandingkan dengan pertumbuhan tanaman pada media yang mengandung tanah.

Baik S. plana maupun S. willdenovii memiliki kandungan flavonoid tertinggi pada kombinasi media tanah : sekam (1:1), yang menunjukkan adanya pengaruh perlakuan media terhadap kandungan flavonoid. Hasil ini sesuai dengan penelitian Susanti (2006) yang menunjukkan bahwa kandungan flavonoid tanaman dipengaruhi oleh kandungan hara media. Berbeda halnya dengan kandungan flavonoid, kandungan saponin tertinggi pada jenis S. plana dan S. willdenovii berturut-turut diperoleh pada tanaman yang ditanam pada media sekam dan arang sekam (1:1) dan media sekam dan arang sekam (3:1). Hasil tersebut menunjukkan bahwa kedua perlakuan media tersebut yaitu media sekam dan arang sekam dengan perbandingan 1:1 dan 3:1 dapat meningkatkan kandungan saponin. Kandungan

Tabel 2. Data analisis media tanam Selaginella

\begin{tabular}{cccccccc}
\hline Media & $\mathrm{C}$ & $\mathrm{N}$ & $\mathrm{P}$ & $\mathrm{K}$ & $\mathrm{Ca}$ & $\mathrm{Mg}$ & $\mathrm{pH}$ \\
\cline { 2 - 8 } & & & & $(\%)$ & & & \\
\hline M0 & 10.99 & 0.27 & 0.61 & 0.56 & 4.06 & 0.74 & 6.40 \\
M1 & 41.13 & 0.48 & 0.19 & 0.19 & 1.38 & 0.36 & 6.90 \\
M2 & 17.76 & 0.25 & 0.14 & 0.12 & 0.82 & 0.16 & 6.60 \\
M3 & 36.44 & 0.39 & 0.16 & 0.31 & 1.00 & 0.30 & 6.60 \\
M4 & 18.20 & 0.28 & 0.22 & 0.15 & 1.28 & 0.20 & 6.50 \\
M5 & 36.09 & 0.40 & 0.22 & 0.35 & 1.12 & 0.26 & 6.40 \\
M6 & 36.39 & 0.44 & 0.94 & 0.62 & 2.80 & 1.18 & 6.60 \\
M7 & 39.19 & 0.45 & 0.19 & 0.38 & 1.27 & 0.32 & 6.50 \\
\hline
\end{tabular}

Analisis media tanam dilakukan di Laboratorium Kesuburan Tanah IPB. M0= tanah, M=sekam, M2=tanah:sekam =1:1, M3 = arang sekam, M4=tanah : arang sekam = 1:1,M5 = sekam:arangsekam = 1:1,M6 = sekam $:$ arangsekam = 3:1, M7=sekam : arangsekam $=1: 3$. 
tanin S.plana paling tinggi terdapat pada perlakuan media tanah dan kombinasi media tanah dan arang sekam (1:1). Perbedaan kandungan senyawa fenol antar perlakuan menunjukkan bahwa keberadaan senyawa tersebut bergantung pada spesies tanaman dan kandungan hara dari media tumbuh (Nahrsteidt \& Butterweck 1997).

\section{UCAPAN TERIMA KASIH}

Penelitian ini terselenggara dengan dana dari Penelitian Dasar dengan surat perjanjian no: 012/ sp2h/pp/dp2m/iii/2007 atas nama Tatik Chikmawati.

\section{DAFTAR PUSTAKA}

Chikmawati T, Setyawan AD. Miftahudin. 2012. Phytochemical Composition of Selaginella spp from Java Island Indonesia. Jurnal Makara Seri Sains 16 (2): 129-13309

Dhalimi A. 2003. Pengaruh sekam dan abu sekam terhadap pertumbuhan dan kematian tanaman panili (Vanilla planivolia Andrews) di pembibitan. Bul Tro 14(2):46-55.

Erlan. 2005. Pengaruh berbagai media terhadap pertumbuhan bibit mahkota dewa (Phaleria macrocarpa (Scheff.) Boerl.) di polibag. J. Akta Agrosia 7(2):72-75.

Gayathri V, Asha VV, Subramoniam A. 2005. Preliminary studies on immunomodulatory and antioxidant properties of Selaginella spesies. Indian J. Phar 37:381-385.

Joy et al. 1998. Medicinal Plants. Kerala: Kerala Agricultural University.
Lee IS, Nishikawa A, Furukawa P, Kasahara K, Kim SU. 1999. Effect of Selaginella tamariscina on in vitro tumor cell growth, p53 expression, G1 arrest and in vivo gastric cell proliferation. Cancer Lett 144(1):93-94.

Lin L, Kuo Y, Chou C. 2000. Cytotoxic biflavonoid from Selaginella delicatula. J Nat Prod 63:627-630.

Man S, Gao W, Zhang Y, Huang L, Liu C. 2010. Chemical study and medical application of saponins as anti-cancer agents. Fitoterapia 81(7):703-14.

Marlina N, Rusnandi D. 2007. Teknik aklimatisasi planlet Anthurium pada beberapa media tanam. Bul Teknik Pertanian 12(1):38-40.

Nahrstedt A, Butterweck V. 1997. Biologically active and otherchemical constituent of the herb of Hypericum perforatum L. Pharmacopsyciatry 30:129-134.

Nicholson R. 2006. Phenolic Compound Biochemistry. Netherlands: Springer.

Risa. 2007. Budidaya Euphorbia. [terhubung berkala]. http:// www.bbpplembang. info/index2. php?option $=\mathrm{com}_{-}$ content\&do_pdf $=1 \& \mathrm{id}=96$. [5 Februari 2008].

Sitompul SM, Guritno B. 1995. Analisis Pertumbuhan Tanaman. Yogyakarta: UGM Press.

Susanti H. 2006. Produksi Biomassa dan Bahan Bioaktif Kolesom (Talinum triangulare) pada Berbagai Asal Bibit, Dosis Pupuk Kandang, dan Komposisi Media Tanam [tesis]. Bogor: Sekolah Pascasarjana, Institut Pertanian Bogor.

Suseno H. 1972. Nutrisi mineral, hubungan air dan metabolisma tumbuhan tropika. Bul Physiol 3:2-3.

Taiz L, Zeiger E. 2006. Plant Physiology 4th Edition. Massachusetts: Sinaur Associates.

Tjitrosoepomo G. 1994. Taksonomi Tumbuhan. Jakarta: PT. Bhratara Karya Aksara. 